Canadian University Music Review

Canadian University Music Review

Revue de musique des universités canadiennes

\title{
Music Studies in the New Millennium: Perspectives from Canada
}

\section{John Shepherd}

Volume 21, numéro 1, 2000

Music Studies in the New Millennium : Perspectives from Canada Les études en musique dans le nouveau millénaire : perspectives canadiennes

URI : https://id.erudit.org/iderudit/1014474ar

DOI : https://doi.org/10.7202/1014474ar

Aller au sommaire du numéro

\section{Éditeur(s)}

Canadian University Music Society / Société de musique des universités canadiennes

\section{ISSN}

0710-0353 (imprimé)

2291-2436 (numérique)

Découvrir la revue

\section{Citer ce document}

Shepherd, J. (2000). Music Studies in the New Millennium: Perspectives from Canada. Canadian University Music Review / Revue de musique des universités canadiennes, 21(1), 7-13. https://doi.org/10.7202/1014474ar

\section{Résumé de l'article}

Canada and the Canadian University Music Review have proved fertile grounds for the development of progressive music scholarship since the 1970s. Such developments had to counter the weight of history, which supported established and securely institutionalized forms of academic music. Yet these progressive developments in turn benefitted from major social and cultural shifts, such as those of the Depression years and of "the sixties." A crucial lever and sustaining force in major developments in progressive music scholarship that were to occur from the 1970s onward was critical theory. Theory now pervades much academic work in music, and has given rise to more sophisticated and varied approaches than was possible in the 1970s. The essays in this volume evidence this sophistication and variety, and bear witness to the way in which the intellectual and social topography of Canada can be argued to have proved especially nurturing to progressive scholarship in music.
All Rights Reserved ( C Canadian University Music Society / Société de musique des universités canadiennes, 2000
Ce document est protégé par la loi sur le droit d'auteur. L’utilisation des services d'Érudit (y compris la reproduction) est assujettie à sa politique d'utilisation que vous pouvez consulter en ligne.

https://apropos.erudit.org/fr/usagers/politique-dutilisation/ 


\section{INTRODUCTION-MUSIC STUDIES IN THE NEW MILLENNIUM: PERSPECTIVES FROM CANADA}

\section{John Shepherd, Guest Editor}

During the last quarter of the twentieth century, two innovations occurred in the academic study of music. The first was the manner in which disciplines such as sociology and social anthropology, and intellectual trajectories such as cultural studies, feminism, structuralism and semiology, post-structuralism, postmodernism, post-colonialism, Foucauldian discourse theory, and gay and lesbian studies began to have far-reaching consequences in terms of how scholars thought and wrote about music. These developments followed, and in many cases became allied with those resulting from the increasing presence of ethnomusicology in the academy. The second innovation was the manner in which distinctions between the disciplines of academic music became less clear as similar questions and issues arose within them, largely as a result of the influx of new ideas from disciplines and intellectual trajectories not principally concerned with music. The complex totality of these innovations has been referred to variously as "the new musicology," "critical musicology," or "cultural musicology."

As James Deaville's Preface attests, Canada has proved a fertile ground for such developments. Not only have individual Canadian scholars played an important role in these innovations. The Canadian University Music Review has itself demonstrated a long-standing commitment to the presence within its covers of disciplinary diversity, as well as to the insights to be gained from the crossing of disciplinary borders. It has also-in its openness to diversity and innovation-proved welcoming to new and challenging insights as well as to scholarship in more established veins. The wealth of this activity has been further enriched by the presence of two languages and the cultural and intellectual diversity that this in turn engenders.

The purpose of this special issue of the Canadian University Music Review is to celebrate the contributions of Canadians and the Canadian University Music Review to the innovations in music scholarship that have occurred over the last quarter of a century or so. It is also to afford an opportunity to a number of Canadian scholars who have been active in critical forms of musicology to reflect on past developments, and to identify those questions and issues in the academic study of music which they see as the most important and the most pressing as a new millennium begins. The scholars who have agreed to contribute to this special issue represent a wide range of academic disciplines within music: historical musicology, music theory, ethnomusicology, music education, and popular music studies. 
One of the more intriguing characteristics of the history of the academic study of music is the manner in which Guido Adler's original, speculative mapping of the field became so influential and so entrenched. This mapping, which dates back to 1885 , was very much rooted in the formation of a German national cultural identity, and a consequent desire in the realm of music to establish and legitimate a canon of European "great works" in which German music figured prominently. Adler's mapping drew a distinction between historische Musikwissenschaft ("historical musicology")—drawn from the writing of historiesand systematische Musikwissenschaft ("systematic musicology")-based upon the idea that, in an ahistorical fashion, musical works could be "entities unto themselves," capable of being analyzed and understood in almost complete isolation from their surrounding circumstances. Adler's mapping subsequently translated in the North American context to a clear division between historical musicology and music theory.

Adler's mapping took on the mantle of a canon, and came to be presented as the self-evident and unquestioned way of thinking about and organizing scholarly work on music. It was based upon and came to entrench the idea that music as an art-form was contained within the parameters of the sounds that embodied it. This concept required a strict differentiation between music, whose intrinsic characteristics became the subject matter of systematische Musikwissenschaft (the realm of the German concept of Idee), and a "music" which could only become apparent in historische Musikwissenschaft (the realm of the German concept of Geist) through biography and the discussion of spiritually embodied concepts. A chasm was in this way created between music and the various ecologies that sustained it. Crossing this divide to reintegrate music with these ecologies became extremely difficult as a consequence of Adler's intellectual mapping. The notion of autonomous art on which it was based and to which it gave expression manifested an internally consistent logic that proved almost impervious to challenge. Crossing this divide became nearly impossible also because of the way in which the mapping provided the basis for the organization of musicology in institutional terms. Challenging the mapping not only came to require intellectual imagination, therefore. It came in time to require a willingness to challenge institutional forms which had behind them the weight of history and the power of social legitimacy.

Meaningful challenges to such forces themselves usually succeed only if they carry with them the weight of history. For example, Joseph Kerman notes the influence that the horrors of World War I and the deprivations of the Depression years exerted on Charles Seeger, commonly regarded as the father of US ethnomusicology. He notes also the relevance of ethnomusicology for a subcontinent rich in indigenous forms of music, as well as the way that European art-music foundered initially in cultural milieux that were to become decidedly populist in comparison with those of Europe. ${ }^{1}$ Again, the way in

1 See Joseph Kerman, Contemplating Music: Challenges to Musicology (Cambridge, Mass.: Harvard University Press, 1985), 155 ff. 
which jazz became accepted in mainstream white culture and also in the academy can be traced to major cultural shifts in the 1920s, shifts associated with the end of World War I and the advent of radio and electronic recording. ${ }^{2}$ Jazz entered the academy in the late 1930s and 1940s as a younger generation of scholars raised on jazz began to obtain academic positions. A similar phenomenon occurred in the 1970s as a younger generation of scholars growing up during the major social and cultural shifts to take place with the end of World War II, and weaned on "the sixties" and various forms of rock music, also began to obtain academic positions.

My point here is to situate "theory." It is tempting-looking back to the beginning of the quite radical innovations that began to take place in the academic study of music during the mid- to late 1970s - to think that "theory," that body of knowledge drawn at the time from sociology and social anthropology, was single-handedly responsible for the inception of major shifts in thinking about music. However, pressure had been building for some time against the exclusive and somewhat uniform character of what was being studied in university faculties, schools, and departments of music, how it was being studied, and who was studying it. The explicit desire for change can be traced back to the work of Charles Keil in the mid 1960s. In 1966, he published a seminal article, "Motion and Feeling through Music," 3 that, in discussing inflections of pitch and rhythm in jazz, challenged the conventional musical theoretical thinking that underlay Leonard B. Meyer's otherwise progressive and influential work. ${ }^{4}$ The publication of John Blacking's How Musical Is $M a n ?^{5}$ in 1973 was to have a major impact in challenging many conventional wisdoms commonly held in the Western world about musicality and its "innate" character. And, more generally, ethnomusicology-in particular through the advocacy of the Society for Ethnomusicology-was beginning successfully to challenge exclusivity in music studies through the securing of positions in faculties, schools, and departments of music. However ethnomusicology was being practiced, and however its object study was being conceptualized, one message was very clear: "music is social."

"Theory" therefore entered the fray in the mid- to late 1970s in a context that was to increasingly favour its effects. It was part of a more organic set of shifts that could be argued to have roots going back to the 1930s, if not before. Its distinctive contribution was, however, to provide a set of tools that made possible direct intellectual challenges to the cluster of self-perpetuating and self-reinforcing assumptions that underlay exclusivity in the academic study of music. The notion that all realities-not just "social" realities-were socially constructed allowed for dispassionate analyses of the intellectual and institutional underpinnings of exclusivity, and for the argument that these underpin-

2 See Neil Leonard, Jazz and the White Americans (Chicago: University of Chicago Press, 1962).

3 Charles M. Keil, "Motion and Feeling through Music," Journal of Aesthetics and Art Criticism 24 (1966): 337-49.

4Leonard B. Meyer, Emotion and Meaning in Music (Chicago: University of Chicago Press, 1956).

5 John Blacking, How Musical is Man?, The John Danz Lectures (Seattle: University of Washington Press, 1973). 
nings were not "givens," unquestionable truths incapable of challenge but, indeed, one set of constructed realities among many possible. What theory made possible can be likened to a doorstop. An opening had been created that could never be shut.

If theory entered the fray in a favourable and organically shifting context, it further enabled if not encouraged the increased velocity of these shifts. Sociology and social anthropology are interesting disciplines among the social sciences in that they do not undertake to study a particular subset of social activities, as is the case with political science or economics, for example. They undertake to study entire sets of human activities: sociology-historically and conventionally-in modern, Western worlds; social anthropology-historically and conventionally - in "traditional" societies. However, the increasingly transnational character of capital, the increasing interconnectedness of the world's regions, nations and communities, and increasing globalization have slowly but surely drawn the interests of the two disciplines closer. While sociology, like social anthropology, has a clear object of study, that of the character, order, and consequence of human relatedness, it is as a result a discipline that readily spills over and contributes to others, while at the same time being subject to developments within them. It has at the same time contributed to, and been influenced by, developments in interdisciplinary intellectual trajectories such as cultural studies, feminism, structuralism and semiology, post-structuralism, postmodernism, post-colonialism, Foucauldian discourse theory, and gay and lesbian studies. Indeed, there was evident towards the end of the twentieth century a split between more established forms of sociology and those influenced by these trajectories. The discipline was widely seen as entering a state of crisis, not only because of internal divisions, but also-and partly as a consequence of these divisions-because it had seemed to pass its role of intellectual leadership to many of these other traditions.

These developments can easily be traced in the study of music. Initial insights made possible by social anthropology and sociology were quickly followed by contributions from feminism, post-structuralism, psychoanalytic theory, gay and lesbian studies, postmodernism, post-colonialism, and so on. The laser visions that seemed to characterize work in the late 1970s have been replaced by scholarship that is more subtle, more nuanced and, probably, of a more lasting character. And developments that could once easily be followed by one individual have been replaced by a veritable floodgate of publications that no one person can follow easily.

These musings, which are hardly systematic, were occasioned by one sentence, a very short but revealing sentence, in Stephen McClatchie's opening contribution to this special issue. He says, "theory came to me: I did not come to it." He goes on to say, "indeed, [theory] was hard to avoid." These two sentences made an impact, because they typify - at least for me-a crucial difference in the situation between then and now. In the 1970s, theory was sought out because it was needed as an intellectual weapon in what was to become, by the 
late 1980s and early 1990s, a fierce dispute over the desired character of the academic study of music. Such confrontations are hardly peculiar to music. They have occurred - and still are occurring - in many other disciplines along somewhat similar lines: lines that get drawn when one paradigm is in the ascendent and another is threatened.

In the 1970s, however, theory was easy to avoid and, once found, difficult to grasp. A conscious effort had to be made to step outside one's disciplinary training and to "get into" the intellectual spaces of other disciplines with their different and, it has to be said, often quite strange and intimidating languages. The problem now is somewhat different. As McClatchie says, "theory first impinged on my consciousness through musicology itself." Rich in theory, the difficulty now is to understand how to approach, use, and teach progressive forms of musicology in ways which make sense for scholarship and students. This requires a sense of pragmatism grounded in what McClatchie calls "the new relevancy of music": the need to understand music in terms of its social and cultural contexts, in terms of the manner in which music can "travel" through time and space, and in terms of what music has to offer to human lives more broadly conceived. This pragmatism, this new-found relevance, resonates with an observation made by Beverley Diamond towards the end of her essay. Relevance for many ethnomusicologists, as for an increasing number of musicologists, has to do with issues of identity and difference. "Rather than abstract theorizing," says Diamond, the exchanges she has with her students and the issues they bring to her "clarify that ethnomusicologists are deeply implicated and complicit in the ways in which social difference has been cast, historically and currently."

In some ways, the five essays which make up this special issue are all quite different. They do not represent a unified picture of progressive music studies at the beginning of the new millennium, neither should they. The field is now, thankfully, far too varied and complex, and any attempt at a unified picture would be totally misleading. But-linked perhaps to this diversity-there is one common trait discernible: that of the kind of grounded engagement identified by Diamond. If McClatchie wrestles with the not easy question of how to put theory into play in the twenty-first century, Paul Théberge lays out the issues currently facing the teaching of popular music studies at the postsecondary level. However, Théberge's essay illustrates that his engagement, together with that evidenced in the other essays, is not discipline-bound. As with all the essays, the engagement, although characterized by disciplinary concerns, has clear implications for other musical disciplines: borders are constantly being crossed with ease and relevance.

The issues facing popular music studies, it can be argued, are, mutatis mutandis, those facing many other disciplines of music. In discussing the problems raised by popular music studies for music theory, therefore, Susan Fast is, in effect, raising issues of central concern for music theory and music analysis as disciplines, and, more broadly, for questions of signification in all kinds of music. Beverley Diamond's important and thought-provoking essay illuminates how modes of ethnomusicological analysis as witnessed in Canada 
change perhaps a little less and "progress" perhaps a little less than we might think. This leads us to realize that we should perhaps be a little more sanguine and a little more reflective about our own disciplinary "advances." Finally, Wayne Bowman reminds us, powerfully and persuasively, that we all do music education, and that we should all contribute to it as an important pedagogical undertaking.

These essays are rich, and the connections between them multifaceted, intriguing, and thought-provoking. I would like to thank my colleagues for writing such memorable essays. I have resisted the temptation to engage in detailed summaries-brief summaries would have been unduly distortiveand to point up possible connections, because such an impulse belongs back in the 1970s, that era of totalizing if not laser visions! The joy of reading lies, indeed, in reading, and it is not the role of an editor to usurp that pleasure. One question does, however, remain - that of "perspectives from Canada." At a conference in the mid-1990s, a well-known US colleague observed to me that he thought that Canadians had made numerous, distinctive and important contributions to progressive work in the study of music. Our immediate dilemma in the fleeting moment of this conversation was to pin down that distinctive character (or characters), and explain how it (or they) had come about.

Of course, we couldn't. Nonetheless, I think that my colleague's observation was well-taken, and deserving of come exploration. I would like to suggest that whatever distinctive character this work does display lies not in being recognizably Canadian, but, rather, in coming from Canada. And if this seems contradictory, I would like to refer back to some observations made by James Deaville in his Preface. Is it possible, he asks, "that this bridging of disciplines is characteristic ... of academic life in Canada?" Is it possible, he continues, "that the intellectual climate of Canada is conducive to such multidisciplinarity as has characterized the journal?" In answering this question, Deaville observes that, "in this case, our small size does matter!"

This is an observation with which I would agree. In 1992, I was invited to give the Davidson Dunton Research Lecture at Carleton University. The honouree is required to reflect on the current state of their discipline in the lecture they give. I found that I could not do this without giving some account of the circumstances of my own intellectual formation. Part of that formation has been in the UK-most of it has been in Canada. I could not help but contrast what I experienced and recalled as the somewhat balkanized and claustrophic intellectual terrain and climate of the UK with a much more open situation in Canada. I believe that the words "fresh air" escaped my lips! My experience was-and continues to be-of spaces-figurative, intellectual, perhaps even literal-to be negotiated with reasonable openness. Linked to this ability to move with ease intellectually is another characteristic. The country and class of my birth were ones which marginalized others. One's subject position was in this respect largely fixed. To Deaville's observation on size, and to my own on easy intellectual movement, I would like to suggest one other: that of being marginalized and also of marginalizing-not in a necessarily personal sense, 
but in that of the more complex subject positions that Canada seems to offer. Perhaps size, relative ease of intellectual movement, and a certain ambivalence of subject position provide Canadians with perspectives and insights not so easily engendered elsewhere.

Be that as it may, this special issue certainly serves to celebrate the contributions made by Canadians and the Review to progressive developments in music studies, and to allow for valuable reflections on the past, the present, and the future. I would like to thank the Board of the Review for the opportunity to edit this special issue.

\begin{abstract}
Canada and the Canadian University Music Review have proved fertile grounds for the development of progressive music scholarship since the 1970s. Such developments had to counter the weight of history, which supported established and securely institutionalized forms of academic music. Yet these progressive developments in turn benefitted from major social and cultural shifts, such as those of the Depression years and of "the sixties." A crucial lever and sustaining force in major developments in progressive music scholarship that were to occur from the 1970s onward was critical theory. Theory now pervades much academic work in music, and has given rise to more sophisticated and varied approaches than was possible in the 1970s. The essays in this volume evidence this sophistication and variety, and bear witness to the way in which the intellectual and social topography of Canada can be argued to have proved especially nurturing to progressive scholarship in music.
\end{abstract}

